\title{
Interactions of Undescribed Drilus Beetle Larvae with Pestiferous Limicolaria flammea (Gastropoda: Achatinidae): Are There Prospects for Biocontrol?
}

\author{
Borisade, Omotoso Abiodun ${ }^{\mathrm{a}^{*}}$, Uwaidem, Yakubu Ismaila ${ }^{\mathrm{a}}$ \\ and Moses J. Falade ${ }^{a}$ \\ ${ }^{a}$ Department of Crops and Horticulture, Crop Bioprotection Unit, Ekiti State University Ado Ekiti \\ Nigeria, P. M. B. 5363, Ado Ekiti, Ekiti State, Nigeria.
}

Authors' contributions

This work was carried out in collaboration between both authors. Author UYI designed the study and wrote the protocol while, author BOA wrote the first draft of the manuscript and performed the statistical analysis. Authors BOA, MJF and UYI managed the analyses of the study. Authors UYI and MJF managed the literature searches. All authors read and approved the final manuscript.

Article Information

DOI: $10.9734 /$ ARRB/2021/v36i1230469
Editor(s):
(1) Dr. Paola Angelini, University of Perugia, Italy.

Reviewers:

(1) Eustachio Tarasco, University of Bari Aldo Moro Bari, Italy. (2) Liu Yongjun, Chinese Academy of Agricultural Sciences. China. Complete Peer review History, details of the editor(s), Reviewers and additional Reviewers are available here: https://www.sdiarticle5.com/review-history/66488

Original Research Article

Received 10 January 2021

Accepted 20 March 2021

Published 20 December 2021

\section{ABSTRACT}

The garden snail, Limicolaria flammea is a seasonal pest of several horticultural crops in most of the agroecological areas in Nigeria. The level of damage to crops is especially enormous in the South because of its ability to feed on different crops and the timing of abundance, the early rain season, which usually coincide with onset of rain-fed crop production which expose seedlings and grown-up crop plants to serious damage. In this study, we recorded occurrence data of Limicolaria flammea in okra, carrot, sweet potato, lettuce and maize within a single multi-crop organic farm in order to understand its food preference. Activities of the predatory beetle larvae, Drilus $\mathrm{sp}$ was observed within the environment. The appearance of the larvae was described and its interaction with $L$. flammea was studied to generate some data on the proportions of snail mortality caused by Drilus $\mathrm{sp}$ and other mortality factors that naturally regulate the population dynamics of $L$. flammea within the environment. There was no statistically significant difference in the average number of snails recorded in the different cropping fields $[\mathrm{F}(4,15)=1.369, \mathrm{P}=0.291]$. The activities of Drilus 
larvae against $L$. flammea was higher in okra and carrot plots as snail mortality due to the larvae attack were significantly higher compared to what was recorded in other crop plots $[F(4,30)$ $=3.998, P=0.01]$. The Drilus larvae predate on $L$. flammea by appertural entry, biting through the soft tissues around the mantle to gain entrance and moult into instar larvae within the snail shell in 15-20 days, leaving its exuviae behind in the shell in all the specimens observed $(n=40)$. The Drilus species being reported in this study is morphologically distinct from other described species in available literature. The study suggested that the Drilus species is less known and there are potentials that the species could be useful in inundative biocontrol approaches for the management of pestiferous gastropod populations.

Keywords: Inundative biocontrol; predatory larvae; mortality; Limicolaria flammea.

\section{INTRODUCTION}

The pulmonate garden snail, Limicolaria flammea (Gastropoda: Achatinidae) (Müller, 1774) occur in uncultivated plots, farms, home gardens, lawns and road sides as herbivores, especially during wet seasons in Nigeria. Although there is no authoritative data on the distribution and abundance of $L$. flammea in different agroecological areas in Nigeria, there are reports on the presence of the species and their potentials to cause economic damage on important plants [1]. Limicolaria flammea attain pest status when the environment is modified for agriculture [2] and they appear to be polyphagous, showing no feeding discrimination for specific types of crops. There is evidence that the spread of $L$. flammea is potentially damaging to horticulture and crop production $[3,4]$. Incidentally, early annual rainfall in Southern part of Nigeria, usually between February and March and commencement of rain-fed cropping activities often coincide with the period of abundance of Limicolaria species [5], hence there is invasion and in synergy, these conditions are suspected to fascinate availability of food and increase in their populations. [6] Feeding activities of land snails in general can be responsible for huge loss on horticultural and ornamental crops in different agroecological regions in Nigeria. Apart from direct feeding on foliage, presence of faecal contaminants and slime trails on leafy vegetables reduce market value. Despite the awareness of the potential economic loss incurable from $L$. flammea invasion of cultivated lands, studies on sustainable prevention and control have not received sufficient attention. There is lack of information on the ecology and interaction of $L$. flammea with its natural enemies that sustain some sorts of ecological balance, which could be exploited in developing sustainable biocontrol component of integrated management approach against the pestiferous gastropod community. Natural enemies of $L$. flammea are known to include mammals, birds and arthropods Collection of wild snails by humans for food and many cultural practices in cropping systems, such as bush burning and deep tilling, exert significant pressure on population dynamics and abundance of land snails and eliminate their tendencies to assume the status of a serious pest. Above all, the larvae of Drilus flavescens beetle, with over 130 species currently documented around the world [7], has been identified as obligate or facultative predator of snails. Drilus larvae attack on snails leave specific marks of their activities in the shell, for example, in form of larvae exuviae within the shell or characteristic entry or exit hole [8]. Recently, the biology of two species of Drilus beetles native to Netherlands and their pattern of predation on black snails was described [9]. Several other reports from different parts of the world indicate that Drilus species are diverse and very many species of the predatory beetle are yet to be described [10].

In a hectare multi-crop farmland in Southern Nigeria, significant damage to vegetative parts of maize, sweet potatoes, okra, lettuce and carrot was caused by feeding activities of $L$. flammea and within the area, predatory activities of undescribed species of Drilus larvae, Drilus sp (Coleoptera:Elateridae: Drilini) community was observed. In this report, we provide first hand observations on propensity of L. flammea to attack specific crops with regards to aspects of food preference behaviours and described the mode of interaction of the Drilus species with the land snails. Quantitative data on intensity of predation by the species of the Drilus larvae beetle within the single organic multi-crop environment was generated and the potentials of Drilus beetle larvae as a 
biocontrol agent of pestiferous gastropods was discussed.

\section{MATERIALS AND METHODS}

\subsection{Snail Distribution and Cause of Mortality}

Samples were collected between August and September 2019 during the rainy season and the study site was selected based on the observed foraging activities of $L$. flammea and interactions between Drilus larvae and $L$. flammea observed in previous years. The rainfall pattern in this region is bimodal, with the first rain around March/April peaking in July, followed by a short break in August. The second rain peak is usually in October and with mean annual rainfall of 2528 $\mathrm{mm}$, mean temperature of $26.9^{\circ} \mathrm{C}$ and relative humidity of $70-80 \%$. The cultivated area was approximately 0.5 acre coverage for each of the following crops; okra, maize, carrot, lettuce and sweet potatoes.

In order to explore the population of snails in relation to crop types, as indicator of food preference behaviour and the predatory activities of Drilus beetle larvae in the different crop plots, five positions measuring $9 \times 9 \mathrm{~m}^{2}$ each were pegged and marked using line rope within each 0.5 acreage. The surveyed area within each plot represented approximately $76 \%$ of the cultivated area. Spotlight collection of live snails and dead snails or shells was done. Thereafter, the dead snails were cracked and opened up to observe the presence or absence of exuviae as evidence of Drilus beetle larvae attack or mortality due to other factors. Photographs of representative samples of snail shells containing exuviae of Drilus larvae was recorded.

\subsection{Interaction of Drilus Beetle with Limicolaria flammea}

In order to prepare photographic evidence of the mode of interaction of Drilus beetle larvae with the snails, randomly selected snails and Drilus larvae (Snail: Drilus, 10:5) were kept in transparent plastic box $(\mathrm{L} \times \mathrm{B} \times \mathrm{H}=30 \mathrm{~cm} \times 25 \mathrm{~cm}$ $x 15 \mathrm{~cm}$ ) and visually observed. The mode of attack and entry of the predatory larvae into the snail was photographed. The time taken by the larvae to emerge from the snail's shell counting from the time it has completely entered the shell was recorded for 40 specimens.

\subsection{Statistical Analysis}

Data on the number of snails collected from the five cropping fields and the number of snails killed due by Drilus larvae and other causes were tested for compliance with parametric statistical procedure and thereafter subjected to Analysis of Variance Test (ANOVA). Where there were significant differences, a post-hoc statistical test was conducted to separate the means using Tukey's honestly Significant Difference (HSD) test.

\section{RESULTS}

\subsection{Visual Appearance of Drilus Larvae}

The larvae is heavily sclerotized with bright orange and black colour mix and hairy. The head and the first segment next to the head is bright orange in colour, the 2nd and the 3rd segments are equally orange but each has two black patches. The first thoracic of the larvae are bright orange in colour. The next five segments (4th8 th) and the legs are black. The rear segments, 9th-11th and the attached legs are deep orange and contrasting to the fore segments (Fig. 1).

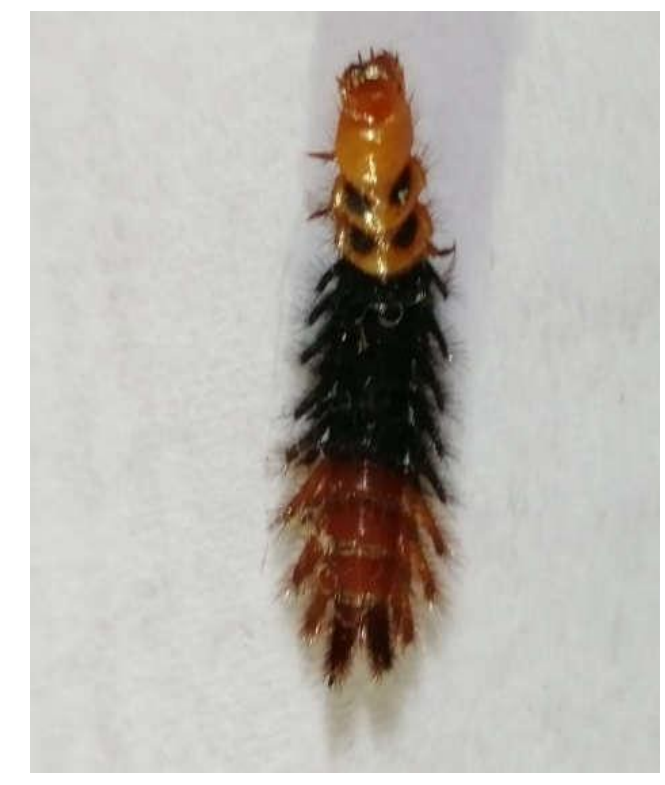

Fig. 1. Photograph of the predatory Drilus beetle larvae

\subsection{Mode of Attack}

The predatory larvae essentially attacked actively moving snails by crawling on the shell from behind and biting through the soft tissues close to the mantle with its highly sclerotized and 
powerful mandibles multiple times, causing retraction of the snail into the shell while the attack continued (Fig. 2). Leakage of body fluid of the snails under attack occurred within 4-6 hours. In the first 6-8 hours of attack, some parts of the larvae remained outside the shell but as the feeding on the soft tissues of the snail continued, the larvae eventually completely entered into the shell. The Drilus larvae remained in the shell for 15-20 days, moult within the shell and emerge to attack another snail within 24 hours. Most of the attacks occurred at night. The exuviae of the larvae was present in the shell of all the snails killed by Drilus larva (Fig. 3).In all the cases observed in this study $(n=40)$, the mode of entry into the snail by the predatory larvae was appertural and moulting occurred within the shell before the emergence of the instar larvae. Each larva attacked and killed up to three snails within a period of eight weeks.

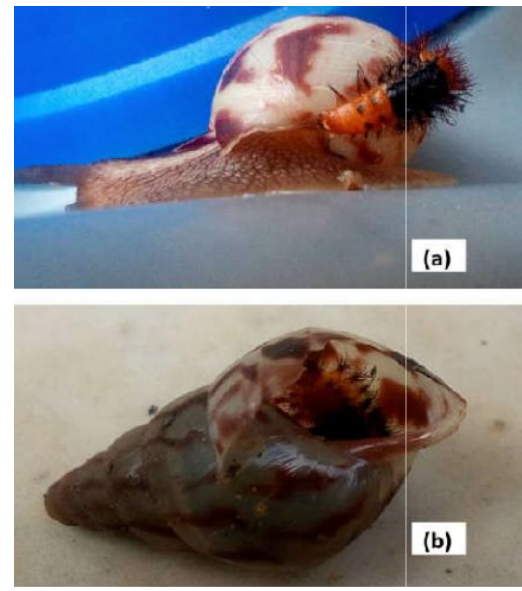

Fig. 2. Larva of Drilus sp pre ying on Limicolaria flammea (a) the predatory larvae crawled on the shell and has bitten the snail multiple times (b) the snail retracted into its shell and the attack continued un til the larvae gained entrance into the intern al organs of the snail

\subsection{Snail Count and Predation by Drilus Larvae}

Table 1. shows the averages of the number of live snails recovered from okra, lettuce, carrot, potatoes and maize plots were not significantly different statistically $[F(4,15)=1.369, P=0.291]$. There were significant differences $n$ the number of dead snails and the empty shells recovered from the different crop fields $[F(4,30)=3.998$, $\mathrm{P}=0.01]$. In the okra, lettuce and carrot fields, significantly higher number of dead snails and empty shells were recovered compared to potato and maize plots. There were significant variabilities in the number of dead snails in relation to Drilus attack and other mortality factors within crop types $[F(4,30)=3.97$, $\mathrm{P}=0.011]$. Evidence of snail mortality due to Drilus larvae attack in okra field was significantly the highest, followed by the value recorded in the field planted with carrot but comparable in maize, potato and lettuce cultivated areas. The number of dead snails and empty shells without Drilus larvae exuviae in the different crop fields were comparable. In the okra, lettuce, carrot, potato and maize fields, Drilus exuviae was found in $69 \%, 18 \%, 50 \%, 50 \%$ and $40 \%$ of dead snails or empty shells respectively.
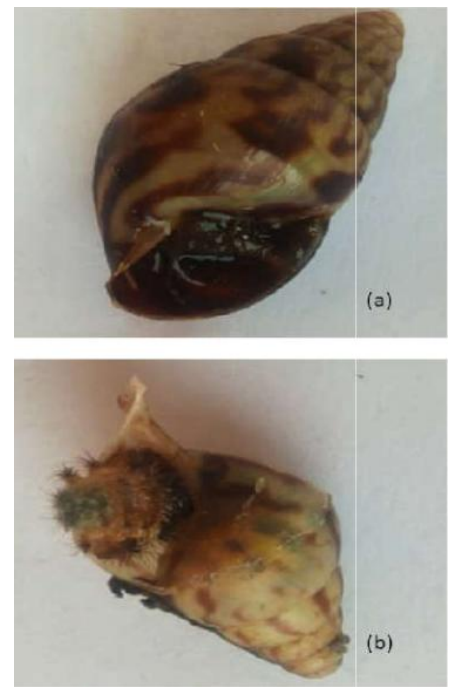

Fig. 3. Limicolaria flammea killed by larvae of Drilus sp (a) dead snail with rotting tissues (b) shell of the dead snail cracked to show presence of exuviae

\section{DISCUSSION}

The Drilus species observed in this study has unique colour patterns and colour intensity that separates it from other species earlier described in many parts of the world where there is occurrence of Drilus species. Baalbergen et al. [9] proposed that colour differentiation is the most obvious character that can be used to separate instar larvae of Drilus species. Several species of Drilus have been described and many more are being discovered. As far as we know, this Nigerian specimen being reported is clearly separated from all previously reported species in terms of external morphology. However, the behaviour of the species as an obligate predator of snails and its mode of interaction with $L$. 
flammea was similar to that described earlier by Baalbergen et al. [9]. The mode of entry of the species is appertural, biting the soft tissue around the mantle to create space for entry. Several species of Drilus are known to bore entry holes on snail shell, but that did not occur between the Drilus species and L. flammea.

The life history of the species was not observed beyond its external appearance and the time taken by the instar larvae to moult and emerge from the shell of the prey, which was 15-20 days for about forty specimens evaluated. In other studies, some species of Drilus emerge from the host shell in about 30 days [9]. It can be suggested that this observed difference in part of the life stage may be characteristic or may be related to effects of temperature and relative humidity. There is currently no study to suggest the effect of temperature on life cycle of Drilus species but aspects temperature and humidity relations as it modulates life cycle of arthropod species are well known. Thus far, it can be suggested that the current Nigerian specimen being reported is an undescribed Drilus species.

The snail, L. flammea had no preference for any of the crops, considering the results of the snail count that showed no significant difference in their average number in the different crop fields. Reports on food preference behaviours in snails showed that highly nutritive and juicy plants such as cabbage, lettuce, watercress, potato skins are the most preferred and snail population density on a particular crop can be considered as an indicator of preference [11]. It was observed that all the sampled crops in the current report were significantly attacked.

Snail mortality due to Drilus attack could be separated from other mortality factors by the presence of exuviae left behind by the instar larvae in the shell [8]. The number of recovered snail shells with evidence of Drilus larvae exuviae was significantly higher in okra and carrot fields but comparable in maize, potatoes and lettuce plots. The ability of a predator to locate its host may vary in different crops as plant morphology may influence the ability of a predator to locate its prey.

In entomological pest-host plant and natural enemies complex, studies have shown that some plants attract natural enemies of pests differentially $[12,13]$ and the possibility of similar interactions in gastropod pest, host and natural enemies complex cannot be ruled out. These may be responsible for the variabilities in the predatory capabilities of the Drilus larvae against $L$. flammea in the different crops. There is no data to compare variabilities in predatory activities, host location capabilities and aggregation patterns of Drilus larvae on snails in different crops. In the okra field, the proportion of snail shells containing Drilus larvae exuviae was $69 \%$ against $31 \%$ by other mortality factors. In all the crop fields examined, Drilus larvae was responsible for a proportion of the dead snails recovered. Other mortality factors in snail populations include birds, some other insects from the Order Diptera and rodents: although these agents were present in the study area, their activities were not identified in the study.

The larvae of Drillus beetle, an obligate predator of snails, was capable of feeding on many snails within its larval stage. Thus, considering the functional role of the predatory larvae on natural population regulation in snail communities, there are potentials in adopting the species for inundative biocontrol of pestiferous gastropods. More so, the female insect in other described species are known to be highly prolific, capable of laying up to 250 eggs that hatch into the larvae within 30 days and seek to attack its first victim within 24 hours after eclosion [9]. The hypermetamorphosis occurring in Drilus species [14,9] that allows prolonged larval form for up to two years is a beneficial quality which could likely enhance its biocontrol capabilities.

Table 1. Estimate of snail count and proportions killed by larvae of Drilus sp and other mortality factors in different crop fields (Mean \pm SE)

\begin{tabular}{llllll}
\hline & & \multicolumn{4}{l}{ Surveyed Crop fields } \\
\hline Parameters & Okra & Lettuce & Carrot & Potatoes & Maize \\
\hline Live snails & $40 \pm 4 \mathrm{a}$ & $37 \pm 4 \mathrm{a}$ & $32 \pm 4 \mathrm{a}$ & $35 \pm 8 \mathrm{a}$ & $32 \pm 7 \mathrm{a}$ \\
Dead snails/shells & $13 \pm 2 \mathrm{a}$ & $11 \pm 3 \mathrm{a}$ & $10 \pm 2 \mathrm{a}$ & $4 \pm 2 \mathrm{~b}$ & $5 \pm 2 \mathrm{~b}$ \\
Mortality by Drilus beetle attack & $9 \pm 1 \mathrm{a}$ & $2 \pm 1 \mathrm{~b}$ & $5 \pm 2 \mathrm{a}, \mathrm{b}$ & $2 \pm 1 \mathrm{~b}$ & $2 \pm 1 \mathrm{~b}$ \\
Mortality by other causes & $4 \pm 1 \mathrm{a}$ & $9 \pm 2 \mathrm{a}$ & $5 \pm 1 \mathrm{a}$ & $2 \pm 1 \mathrm{a}$ & $3 \pm 1 \mathrm{a}$ \\
Mortality by Drilus (\%) & 69 & 18 & 50 & 50 & 40 \\
Mortality by other causes (\%) & 31 & 82 & 50 & 50 & 60 \\
\hline
\end{tabular}




\section{CONCLUSION}

It was concluded that Drilus species is less wellknown, but it has the potential to be useful in inundative biocontrol approaches for pestiferous gastropod population management. In line with good ethics in Integrated Pest Management strategies, bioprospecting for new species is key and it is clearly necessary to document this Nigerian Drilus $\mathrm{sp}$ and its activities on the pestiferous L. flammea populations. However, detailed studies are required in the aspects of taxonomic classification, bioecology and the life history of the species.

\section{COMPETING INTERESTS}

Authors have declared that no competing interests exist.

\section{REFERENCES}

1. Oke OC, Chokor JU. The effect of land use on snail species richness and diversity in the tropical rainforest of south-western Nigeria. African Scientist. 2009;10(2):95108.

2. Awodiran MO, Ogunjobi ZO. Genetic diversity in two populations of Limicolaria aurora from two ecological zones in Nigeria. African Journal of Biotechnology. 2016;15(25):1306-1314.

3. Slug G, Pradesh H. Gastropod pests of vegetables crops. Science Horizon, 2017; 35.

4. Justin $\mathrm{ON}$, Bernadette TCL, Yawa ME, Mercy NAD, Mathias MA. Spatial distribution and seasonal variation of Limicolaria spp. infesting banana plantations in South West, Cameroon. World Journal of Advanced Research and Reviews. 2019;3(2):036-045.

5. Tyowua BT. Assessment of distribution and abundance of land snail species in makurdi metropolis, Benue State, Nigeria. Nigerian Journal of Wildlife Management (NJWM). 2017;1(1).
6. Barker GM. Natural enemies of terrestrial molluscs. CABI; 2004.

7. Kundrata R, Bocak L. Taxonomic review of Drilini (Elateridae: Agrypninae) in Cameroon reveals high morphological diversity, including the discovery of five new genera. Insect Syst. Evol. 2017;48: 441-492.

8. Němec T, Horsák $M$. Specific damage recognised on land snail shells as a tool for studying predation intensity: differences related to habitat and predator types. Contributions to Zoology. 2019;1:1-20.

9. Baalbergen E, Schelfhorst R, Schilthuizen M. Drilus larvae in the Netherlands (Coleoptera: Elateridae: Drilini). Entomologische Berichte. 2016;76:165173.

10. Sormova E, Kundrata R. Diversity and phylogenetic relationships of Drilus Olivier, 1790 (Elateridae: Agrypninae: Drilini) in Cyprus. Zoologischer Anzeiger. 2018;275: 1-12.

11. Lindinalva dos Santos, Carla Ruth de Carvalho Barbosa-Negrisoli, Maciel Bispo dos Santos, Aldomário Santo Negrisoli Junior. Population fluctuation and food preference of African snail by horticulture crops, Agroecology / Scientific Article; 2018.

12. Xiu C, Zhan, W, Xu B, Wyckhuys KA, Cai $X$, Su $H$, Lu Y. Volatiles from aphidinfested plants attract adults of the multicolored Asian lady beetle Harmonia axyridis. Biological Control. 2019;129:1-11.

13. Rashedi A, Rajabpour A, Rasekh A, ZandiSohani N. Interactions between host plant, Aphis fabae, and its natural enemies, Orius albidipennis and Lysiphlebus fabarum in a tritrophic system. Journal of Asia-Pacific Entomology. 2019;22(3):847-852.

14. Faucheux MJ. Antennal sensilla of the primary larva of the false firefly beetle Drilus mauritanicus Lucas, 1849 (Coleoptera, Elateridae, Agrypninae, Drilini). Bulletin de l'Institut Scientifique, Rabat. 2014;36:57-64.

(c) 2021 Borisade et al.; This is an Open Access article distributed under the terms of the Creative Commons Attribution License (http://creativecommons.org/licenses/by/4.0), which permits unrestricted use, distribution, and reproduction in any medium, provided the original work is properly cited.

Peer-review history:

The peer review history for this paper can be accessed here: https://www.sdiarticle5.com/review-history/66488 